\title{
Foreign Language Training Transformation for Sustainable Development: Trends and Experiences
}

\author{
Dinara Ivanova, Anna Polenova*, and Anna Motozhanets \\ Southern Federal University, Bolshaya Sadovaya Str., 105/42, 344006 Rostov-on-Don, Russia
}

\begin{abstract}
The aim of this paper is to analyze the ways and identify the main trends of language learning transformation in universities for sustainable development in order to encourage students' soft skills and competences for real commitment and interaction. Education is considered as a means through which individuals can improve their quality of life. If we redesign institutional educational programs on language learning based on students' needs and expected outcomes, then both the quality of language education and the quality of life will improve dramatically. It also tries to consider the directions to implement sustainability in foreign language teaching through curriculum, interdisciplinary approach and innovation.
\end{abstract}

\section{Introduction}

Education is the central element of sustainable development along with other relevant indicators within the Sustainable Development Goals. In the last decades several international commissions and organizations agreed on the importance of Education for Sustainable Development (ESD). Such global issues as climate change or poverty reduction, clean energy or quality of life require changing our life and transforming the mentality and activity vector. Education is considered as a means through which individuals can improve their quality of life. To achieve this major change, we need new skills and competencies to successfully handle difficult and unfamiliar situations and reflect on one's own acts and ideas that lead to more sustainable societies. Consequently, Education for Sustainable Development (ESD) is introducing new approaches as it marks a new culture of education and a new direction in teaching and learning of content and methods. ESD means incorporating central issues of sustainable development into education and learning and supporting the acquisition of competencies that enable people to live and act in a sustainable way. The key to implement sustainability is closely linked to the curriculum and the interdisciplinary approach to education. Education systems should respond to these pressures by defining key learning objectives, introducing teaching methods centered on learners, and asking their institutions to reflect sustainability principles in their managerial bodies [1]. Universities are expected to play a role of a change agent to fuel community development through inter-generational learning, to develop their own way of sustainable

\footnotetext{
${ }^{*}$ Corresponding author: polenova_a@list.ru
} 
growth by creating knowledge, skills and jobs and to help society to achieve a more sustainable future. The aim of this paper is to analyze the ways and identify the main trends of language learning transformation in universities for sustainable development in order to encourage students' soft skills and competences for real commitment and interaction.

\section{Materials and Methods}

Following the principles of ESD that is focused on enabling all people to acquire knowledge and skills required for shaping their own way of life and society in a sustainable way, educational institutions within a society have to implement the programs of education for sustainable development or sustainability education [1]. So, efforts were made to rethink and revise educational programs towards sustainability, which are important for present and future communities. Some scientists and educationalists in the area of language teaching expressed the necessity to integrate programs of education for sustainable development into higher education. It was also noted that language learning can contribute a lot to a number of interdisciplinary collaborations. The universities should integrate foreign language education into their curriculum in order to enable future professionals to cope with issues of sustainable development in their work and to reinforce sustainability competencies of students. According to UNESCO , education for sustainable development relates to the core of teaching and learning, integrating new concepts into the curriculum. An important factor for changes in curriculum and teaching practice is the new approach for a sustainability-centered education and a whole-person approach to educating students where teachers are the most important drivers for restructuring educational process and moving educational institutions towards sustainability. To ensure the smooth process they must develop sustainability key competencies (knowledge, skills, attitudes, values, motivation, and responsibility) through a range of innovative teaching and learning instruments. Internationalization process is an essential element to facilitate ESD through the use of international debates, based on cultural diversity, providing the opportunity to study abroad, explore practical experiences.

The research is based on the assumption: if we redesign institutional educational programs on language learning based on students' needs and expected outcomes, then both the quality of language education and the quality of life will improve dramatically. It also tries to consider the directions to implement sustainability in foreign language teaching through curriculum, interdisciplinary approach and innovation.

\section{Results and Discussion}

\subsubsection{Introducing students' code of behavior to provide more sustainable teaching}

It is widely accepted that as the methodologist P. Ur suggests "teenage students are in fact overall the best language learners"[2]. However, it is only part of the whole picture. It is true that university teachers are able to make the process of learning and teaching more effective and sustainable by introducing some basic rules of behavior. If this challenge is met, university teachers actually manage to control their students if "this is done in a supportive and constructive way so that he or she helps rather than shouts [3].

When our English learners arrive at university, it is strongly recommended to create a code of conduct for both university teachers and students to allow to organize the learning and teaching course in the most sustainable way. The code, which refers to a more formal way of keeping a sustainable development, should be based on the mutual expectations of the learners and those who teach. . As we perceive learning and teaching as some kind of 
interaction between two actively involved in this process parties, we strongly believe that these two parties have to agree the terms in the first place. There is much more to note here. University teachers ought to understand the learners' needs and expectations as it is definitely not an one-sided process. As teachers of university we have to start with the recognition of learners as individuals. What is to be done then?

There have traditionally been a few productive techniques that our professors apply to clarify what exactly is required from the students. There is no denying that those who teach expect the students not to be late for classes. We also want the students to come with their homework done. The fact is that we normally expect our students to be engaged as much as possible and hand in their works on time. There is nothing special about giving these instructions and we are sure that they should be given in English. Apart from the obvious fact that the more English language we expose our students to, the more they will learn, we agree with P. Harbond who suggests "the giving of instructions and many other teacherstudent interactions are an ideal source of language for students acquisition". This approach might help create an English -speaking environment, as well as it makes English the classroom language as well as the language to be learned.

If university teachers manage to set clear guidelines, part of the agreed code of conduct with a class becomes just understanding of when and what is more or less acceptable and when and what is seriously counter-productive.

However, by keeping our eye on our students' expectations we are ready to organize the teaching process in the most effective and sustainable way. For example, during the first class professors teaching in universities while introducing their course syllabuses are supposed to conduct learners' needs analysis. It might seem that as students must be aware of the course aims, task description, due dates, and grading policy teachers need to understand students' wants. All of this is essential, because as H. Puchta and M. Schratz see the problem with this age category as resulting, at least in part, from ..."the teacher's failure to build bridges between what they want and have to teach and theirs students' worlds of thought and experience" [4].

However, it does not mean we should abandon our own teaching beliefs because the students are not used to what they are required to do. It means, in our opinion, initiating gradual rather than intermediate change We should remember about the friendly encouragement and persuasion while we are trying to introduce all these things used for managing English classes sustainably and effectively for long periods.

\subsubsection{Content and language integrated learning (clil) as a trend for sustainable development}

While a big number of those who study English in our country concentrate on "general English" as all-purpose language with no focus on one professional area, the specific feature of universities is that foreign language teaching must be in the area of English for Specific Purposes (ESP) to promote sustainability in the further professional development. And it is not surprising that the increasing amount of students perceive an urgent need for this particular kind of language and see it as one of the major means of improving their professional career prospects. As a matter of fact, they are eager to be confident about their specific vocabulary, as armed with this confidence and speech skills they are more likely to operate sustainably and effectively in their profession. ESP requires a certain type of discourse and specific expressions which are to be taught at university level and which would be out of place in normal communication. There are also some language events such as presenting to colleagues, the language of professional contacts, dealing with dissatisfied clients, which are highly unlikely to to be taught in a general foreign language course. As a result we as university teachers find ourselves training classes in different professional 
environment they may encounter in their future career. For instance, we arrange such procedures as the art of negotiating, the correct use of phones and emails, making contracts or reports. We actively engage CLIL methodology (CLIL- Content and Language Integrated Learning) that encourages studying both language and special subject [5-7]. CLIL method develops an extended range of language skills and knowledge within the students' professional area and activities along with extra linguistic skills such as decisionmaking, team work, and critical thinking- those highly required by the potential employers. CLIL classes give us an excellent opportunity to avoid monotonous routine of English language classes focused on reading and translation. Moreover, studying special subjects using English as a medium of instruction creates a new sort of educational environment that enhances students' creative skills, their ability to adapt to cooperation and professional communication. Consequently, CLIL method facilitates students' autonomy in professional and communication context. Learning through professional subjects entails learning not only the knowledge of the discipline but also the skills associated with the production of knowledge within the discipline. Through subject curriculum and instruction students should learn why the discipline is important, how experts create new knowledge, and how they communicate about it. Each of these steps maps closely to the development of $21 \mathrm{st}$ century skills and knowledge. Developing other 21 st century skills, such as leadership, adaptability, and initiative, can also take place through the disciplines when teachers explicitly define those objectives and facilitate ways for students to develop them. For example, teachers can design activities in which students practice rotating leadership responsibilities in groups, tutor younger children, or work with their local communities.

\subsubsection{Online foreign language education}

A. Piper in his article [8] suggested that the most successful educational use of the computer at that time was an word processor, with students grouped around a screen drafting and redrafting collaboratively. We do not see any reason to completely revise this judgement even though many years have passed since it was made. Computers today are perceived as one of the most powerful tools for sustainable long life development.

The digital revolution transformed early twenty-first century life dramatically. The pandemic of COVID-19 has resulted in universities closed down all over the world. We have all witnessed the distinctive growth of e-learning, while teaching has been undertaken remotely on various digital platforms. These developments turned out to be of inestimable value for both university teachers and students. Although many professors have criticized this format, it would be unwise to deny that online learning takes less time and all the gadgets offer a rich diet of activities promoting students' enthusiasm and motivation. Students who have been sitting behind their desks for many hours find themselves "playing" with some language tasks and might well perceive e-learning as a welcome relief.

With this rapid and dramatic shift away from the university classroom to their computers, laptops and tablets, some professors wonder if the introduction of online learning will persist post-pandemic, and how such a shift will influence education. All we can be sure about is that there are marvelous new technological developments round the corner. Of particular interest for those who teach foreign languages online is the fact that this format has a huge potential for good computer-users. One of the biggest advantage of online learning, in our opinion, is that teachers and students have had access to authentic English And we need to remember that things will never be the same taking into account this huge potential of e-learning for sustainable course of self-development.

Technology offers the potential to provide students with new ways to develop their problem-solving, critical thinking, and communication skills; transfer them to different contexts; reflection their thinking and that of their peers; practice addressing their 
misunderstandings; and collaborate with peers. The nature of the Internet's countless sources, many of which provide inconsistent information, provide students with the opportunity to learn to assess sources for their reliability and validity. It gives them an opportunity to practice filtering out information from unreliable sources and synthesizing information from legitimate ones.

\subsection{Learner autonomy as the key factor of sustainable learners' development}

\subsubsection{The independent learner}

To find compensation for the limits of university classroom time, students should develop their own learning strategies, so that as far as possible to ensure sustainable selfdevelopment and language acquisition for their future life. We definitely agree with S. Cotterall who points out that "a teacher will not always be around if and when students wish to use the language in real life"[9].

However excellent a professor is, students will never know a foreign language properly unless they study it outside the classroom. The view that an independent learner must more clearly understand the objectives of their learning programme is shared today by almost everyone. As H.Holec and D.Little suggest "Independent learners accept responsibility for their learning process share in the setting of learning goals, take initiatives in planning and executing learning activities, and regularly review their learning and evaluate its effectiveness " [10-11]. It is widely accepted that the practice of learner independence supposes insights into the learning process as well a, a positive attitude to this process. This definition captures the main challenges of learner independence. It reveals some kind of a holistic belief that allows us to engage with the cognitive, affective and social aspects of language acquisition.

A lot of university teachers worry about the passivity which we regard as an enemy of sustainable learning. And although independence of action is welcomed in the educational environment of the university we work in these days, there are no still enough facilities to motivate our students to become independent learners. Perhaps the first thing we would like to highlight here is that students become enthusiastic about self-learning and selfdeveloping when they grow older. So we strongly believe it is essential to encourage students to become effective and efficient independent long life learners. In the light of $t$ what we have said so far we perceive our goal as making students get interested in the language acquisition to provide a sustainable course of language education in the future.

\subsubsection{Routes to sustainable long life learning}

So far we can boast that our university teachers have created a rich mixture of activities promoting sustainable long life learning. In the English course we teach we stimulate students to reflect how efficiently and effectively they learn, provide them with different techniques for dealing with various activities and challenges. We highlight the fact that learning techniques in university are rather different from those they applied in their secondary schools. Thus, they must come to the conclusion that they are obliged to improve their school techniques as well as work out brand new ones which are best for their learning environment.

Self-reflection allows students to understand better their strengths and weaknesses with a view to arranging a blueprint for a future sustainable development. For instance, we may ask students to fill in a questionnaire in which they profile their ideas about various aspects of language. Furthermore we might probe the students' self-analysis, considering the issues 
such as why listening is challenging and what techniques can be used to improve listening skills. What really matters is that all these things must not go unnoticed for our students. Then it is time for university teachers to discuss with the students their learning experiences. Once the students have made some progress they might be asked to get insights into their own progress by answering questions about how productively they reckon they have learned the material. It is vitally important for the university teachers to give students help and recommendations about how to arrange independently a sustainable learning process when they have stopped attending the core course of English in university.

The best conclusion to make from what we have written so far is that all the university teachers who give a course of a foreign language in higher schools are supposed to be armed with a rich diet of various methods and techniques, as it is not easy to reveal which one is best and most appropriate for our present teaching environment. So our instructions should be as clear and encouraging as possible. As S. Krashen points out[12] only "comprehensible input aids language acquisition" and provides a more sustainable learning. Another crucial issue is the one which refers to the well-established universal techniques which might be applied for teaching any course. Online teaching we face today in the time of the pandemic implies more active students' involvement in educational process at all stages. So our conclusion is that this reality is tantamount to the so-called pragmatic eclecticism where decisions about the content and the form are based on what seems to work. There are good reasons why we should take into account what goes well in our classrooms and outside them. However, we do not want to say that this pragmatic eclecticism does not mean that «anything goes». It is hardly surprising that students today are, to some extent, better than teachers armed with skills dealing modern technologies. So they have the right to be asked to do activities for a good reason, and those who are responsible for teaching are expected to have some goals in minds which they must articulate clearly to provide the desirable sustainable learning.

\section{Conclusions}

In conclusion, the findings of this paper imply the need to redesign foreign language teaching policies according to the principles of sustainable development that aim at developing social, economic and environmental knowledge that will assist students in tackling the problems of modern life. The main directions to change the existing policy should cover the following:

- Foreign language learning should be practice/project based process including various types of assistance such as coaching and internships. It will encourage students' skills in creation, design, presentation and evaluation of their works along with the development of partnerships and cooperation between universities;

Assessment and evaluation systems should be reconsidered since they are a powerful indicator of students progress and are essential for curriculum development highlighting student satisfaction level;

- Foreign language learning should be based on ICTs that could provide access to global information sources and knowledge databases.

- Foreign language courses in system of Higher Education should become an ingredient of various lifelong and entrepreneurial programs since they develop social responsibility via studying and make our specialists ready to compete in international business environment;

- $\quad$ Foreign language learning in university should be reliable in terms of information quality providing students with analytical, critical and technical skills;

- Foreign language learning should be aimed at the principles of sustainable education by providing access to e-resources and online formats of teaching to advance 
knowledge and to share experiences to different stakeholders such as students, professors, companies and government institutions.

\section{References}

1. UNESCO, Education for Sustainable Development Goals, (2017), https://www.developmenteducation.ie/

2. P.Ur., A Course in English Teaching,96 (2016)

3. J. Harmer. How to teach English. Pearson Education Limited, 2nd Edition, 22 (2010)

4. H. Putcha, M. Schratz, Teaching teenagers. Pearson Education Ltd, 4 (1998)

5. D. Coyle, Ph.Hood, D. March, CLIL:Content and Language Integrated Learning (2010)

6. P.Mehisto, D.Marsh, M. Frigols, Uncovering CLIL: Content and Language Integrated Learning in Bilingual and Multilingual Education (2008)

7. U. Smith, English as a Lingua Franca in Higher Education. A Longitudinal Study of Classroom Discourse (2010)

8. A. Piper, ELT Journal, 42/1 (1987)

9. S. Cotterall, ELT Journal, 49/3, 220 (1995)

10. H. Holec, Autonomy and foreign language learning, 49 (2001)

11. D. Little, Language Teaching, 182 (2002)

12. S. Krashen, The Input Hypothesis Issues and Implications. Longman (2009)

13. A. Fortune, ELT Journal, 46/2, 168 (1992)

14. D. Nunan, Designing Tasks for the Communicative Classroom (1989)

15. W. Fischman, J.A. DiBara, H. Gardner, Cambridge Journal of Education, 36(3), 383 (2006)

16. W. Fischman, H. Gardner, Knowledge Quest, 37(3), 74 (2009)

17. A. J. Wayne, K. S. Yoon, P. Zhu, S. Cronen, M. S. Garet, Educational Researcher, 37(8), 469 (2008) 